\title{
Arbuscular mycorrhizal fungi associated with adaptive plants in gold mine tailing
}

\author{
FAISAL DANU TUHETERU ${ }^{1, \bullet}$, HUSNA $^{1}$, ALBASRI ${ }^{1}$, ASRIANTI ARIF $^{1}$, SUTRI AYU WULAN $^{1}$, \\ KARTINI KRAMADIBRATA ${ }^{2}$ \\ ${ }^{1}$ Department of Forestry, Faculty of Forestry and Environmental Science, Universitas Halu Oleo. Jl. Mayjen S. Parman, Kemaraya, Kendari City \\ 93232, Southeast Sulawesi, Indonesia. Tel.: +62-401-3190105, `email: fdtuheteru1978@gmail.com \\ ${ }^{2}$ Herbarium Bogoriense, Botany Division, Research Center for Biology, Indonesian Institute of Science. J1. Raya Jakarta-Bogor Km 46, Cibinong, Bogor \\ 16911, West Java, Indonesia
}

Manuscript received: 16 August 2019. Revision accepted: 29 October 2019.

\begin{abstract}
Tuheteru FD, Husna, Albasri, Arif A, Wulan SA, Kramadibrata K. 2019. Arbuscular mycorrhizal fungi associated with adaptive plants in gold mine tailing. Biodiversitas 20: 3398-3404. Arbuscular mycorrhizal fungi (AMF) are fungi from division Glomeremycota within the kingdom Fungi, which have a broad ecological range and symbiosis with a variety of vegetations, including vegetations in gold post-mining areas or gold tailings. The study of identifying types of AMF in gold tailings in Southeast Sulawesi is still limited. The purpose of this study was to identify the types of AMF in the rhizosphere of adaptive plants in gold tailings land in Bombana District, Southeast Sulawesi. Soil samples were collected from adaptive plants in Perseroan Terbatas (PT) Panca Logam Makmur, Bombana District, Southeast Sulawesi Province, Indonesia. AM Fungi spores were isolated and identified based on their morphological characteristics (shape, size, color, attached hyphae, and spore ornamentation). Five types of AMF were identified, namely Glomus aggregatum, Sclerocystis sinuosa, Acaulospora scrobiculata, A. tuberculata, Scutellospora pellucida, and two genera that had not been identified up to species, Glomus sp. and Scutellospora sp. In addition to spores, the symbiosis of AM Fungi with adaptive plants was also demonstrated by the structure of AM Fungi in plant roots with a rate of $74 \%$ colonization. S. pellucida and $S$. sinuosa were recorded as new species in Indonesia and Sulawesi, respectively. While A. tuberculata is a type of AMF that enriches AMF diversity in Southeast Sulawesi.
\end{abstract}

Keywords: External hyphae, Glomeromycota, gold tailings, pioneer plants, Southeast Sulawesi

\section{INTRODUCTION}

Deforestation is one of the main causes of biodiversity loss in tropical ecosystems (Achard et al. 2002). One activity that contributes to deforestation in the tropics is mining activities. Mining activities can have an impact on decreasing biodiversity, including soil biota such as arbuscular mycorrhizal fungi (Sheoran et al. 2010; Wang 2017). This group of fungi is an important component of soil microbes (Jeffries et al. 2003) and can promote ecological restoration of mining-impacted sites (Wang 2017), is symbiotic with the majority of terrestrial plants in the tropics (Smith and Read 2008) and is also found in inundation conditions (Tuheteru and $\mathrm{Wu}$ 2017). Until now there are around 315 types of AMF in the world (www.amf-phylogeny.com/amphylo_species.html).

Seventy-two types of them have been reported to be symbiotic with plants in various conditions of land use and ecosystems in Indonesia (Husna et al. 2018).

Jean-Philippe et al. (2011) stated that when a disturbance occurs (anthropogenic mercury emissions), Arbuscular mycorrhizal fungi (AMF) is an important component for the sustainability and development of postdisturbance vegetation. They also stated that it is important to identify the types and abundance of AMF in a disturbed environment. Exploration and identification of AMF and adaptive plants on gold tailings land have been carried out in Indonesia including in Timika Papua (Suharno et al. 2014; 2016; 2017), Lombok West Nusa Tenggara (Utomo et al. 2014) and Mandailing Natal, North Sumatra (Delvian et al. 2016) and in South Africa (Straker et al. 2007). The results of these studies reported that the symbiosis of adaptive plants with AMF can accelerate adaptive plant succession in gold post-mining land conditions. The limitation of these studies was that the identity of the AMF types has not been clearly revealed.

In addition to these limitations, there has been no study conducted in relation to the symbiosis of AMF with adaptive plants in gold tailings in Southeast Sulawesi. Therefore, this study was conducted to identify the types of AMF that are symbiotic with various adaptive plants in gold tailings fields in Southeast Sulawesi. The study on the identification of AMF types in Southeast Sulawesi was reported in the rhizosphere of Pericopsis mooniana (Thw.) on a variety of land conditions (Husna et al. 2014; 2015). The long-term goal of this study was to obtain a collection of AMF types that have the potential to be developed as biological fertilizers to support the restoration of gold mining or tailings land in the tropics. 


\section{MATERIALS AND METHODS}

\section{Sampling and preparation of soil material}

A total of 30 soil samples were collected from the adaptive plants of gold tailings land at a private company (PT). Panca Logam Makmur. Bombana District, Southeast Sulawesi Province, Indonesia (Figure 1). Soil samples were taken from the rhizospheres of adaptive plants of the gold tailings land. There were 30 plots designated as soil sampling points. One kilogram of soil sample from soil depth of 0-20 cm was taken from each plot. Each soil sample was put into a plastic bag and coded by the name of each plot. The unidentified plants located nearby the sampling points were identified at Herbarium Bogoriense Indonesian Institut of Sciences (LIPI), Bogor, Indonesia. All soil samples were air-dried in the laboratory for the purpose of isolation and identification of AMF spores. The composite soil $( \pm 1 \mathrm{~kg})$ was sent to the Soil and Plant Laboratory of SEAMEO BIOTROP, Bogor, Indonesia. The results of soil analyses are presented in Table 1. Mean annual rainfall varies from $1083 \mathrm{~mm}$ to $1325 \mathrm{~mm}$.

\section{AMF colonization}

Root samples were cleaned and preserved in $70 \%$ alcohol solution. AMF colonization was observed using trypan blue dye (Phillips and Hayman 1970) and was counted using the following formula (Brundrett et al. 1996):

AMF colonization $=$ Field of view of mycorrhiza $\times 100 \%$ Total observed field of view

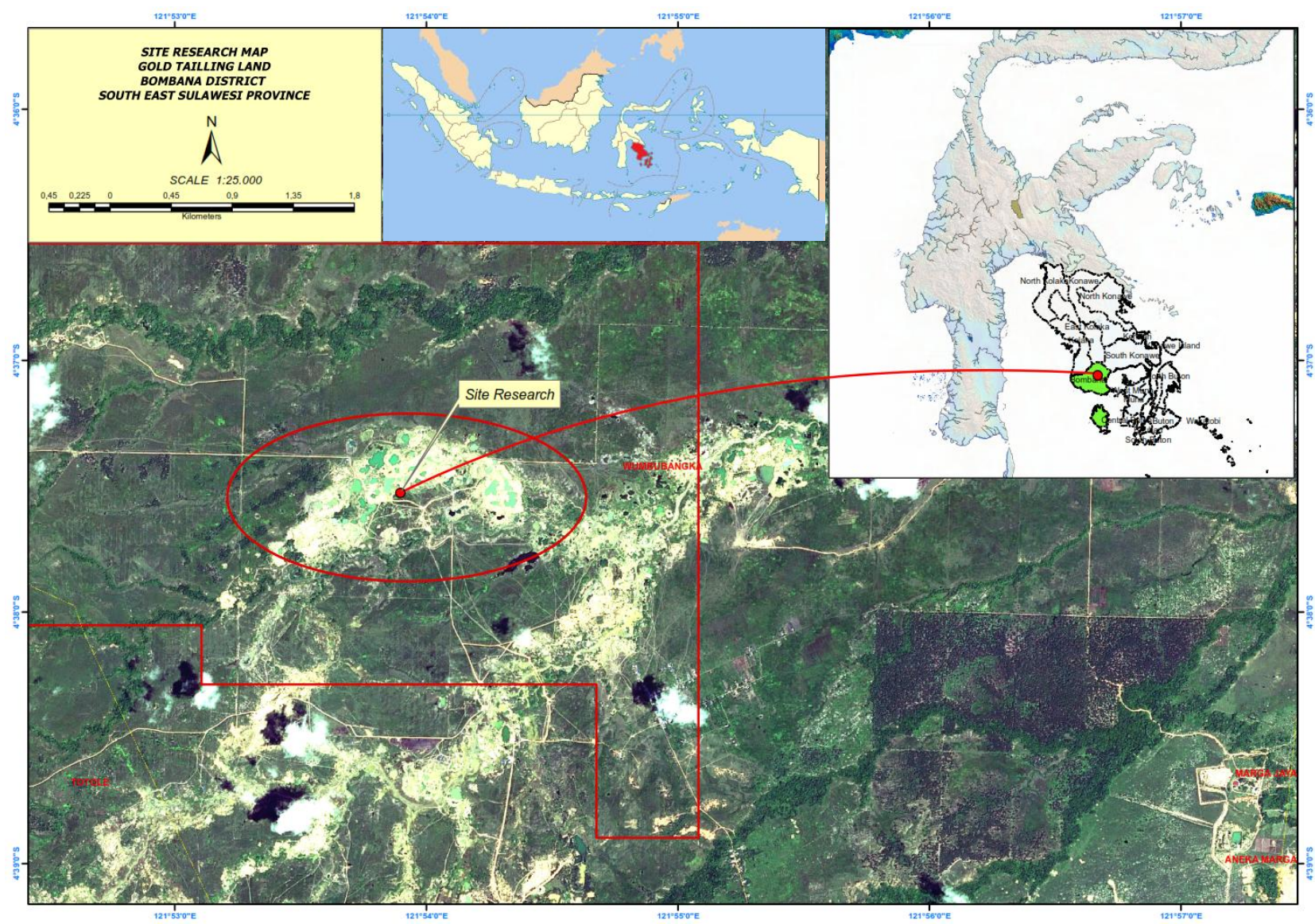

Figure 1. Map of study site in Private Company of Panca Logam Makmur, Bombana, Southeast Sulawesi, Indonesia

Table 1. Chemical and physical properties of gold post-mining soil at Private Company of Panca Logam Makmur, Bombana, Southeast Sulawesi, Indonesia

\begin{tabular}{|c|c|c|c|c|c|c|}
\hline \multirow{3}{*}{$\begin{array}{l}\text { Sample } \\
\text { code/plot }\end{array}$} & \multirow{2}{*}{\multicolumn{2}{|c|}{$\begin{array}{c}\text { *pH (1:1) } \\
\text { SNI 03-6787-2002 }\end{array}$}} & \multirow{3}{*}{ 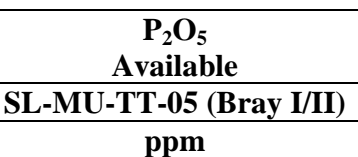 } & \multicolumn{3}{|c|}{$\begin{array}{c}\text { Texture } 3 \text { fractions } \\
\text { SL-MU-TT-10 (hydrometer) }\end{array}$} \\
\hline & & & & Sandy $(50 \mu-2 \mathrm{~mm})$ & Dust $(2 \mu-50 \mu)$ & Clay $(0,2 \mu-2 \mu)$ \\
\hline & $\mathrm{H}_{2} \mathrm{O}$ & KCl & & $\%$ & $\%$ & $\%$ \\
\hline $1-10$ & 7.1 & 5.5 & 15.2 & 85.1 & 3.0 & 11.9 \\
\hline $11-20$ & 5.8 & 3.9 & 12.3 & 51.9 & 13.6 & 34.5 \\
\hline $21-30$ & 6.7 & 5.1 & 11.6 & 85.5 & 1.9 & 12.6 \\
\hline
\end{tabular}




\section{Isolation and identification AMF}

$100 \mathrm{~g}$ of soil was sieved and decanted for spore recovery using the method of Gerdemann and Nicolson (1963) and continued with a centrifugation technique from Brundrett et al. (1996). Healthy spores were selected and stored on glass objects that had been given a drop of PVLG solution and then covered with a closing glass and were observed under compound microscope (OLYMPUS CX22LED). Identification of AMF spores was carried out by observing morphological characters i.e. shape, size, color, attached hyphae, and spore ornamentation. For spore identification, the manual for identification of VA mycorrhizal fungi by Schenck and Perez (1990) was used and the names of AMF spores were identified based on literature from Schüßler and Walker (2010); Redecker (2013).

\section{RESULTS AND DISCUSSION}

\section{AMF colonization in vegetation roots}

The average AMF colonization obtained from this research was $73.9 \%$ with a range of $43-97 \%$. The structure of AMF was found in adaptive plant roots as external hyphae, internal hyphae, vesicles, hyphae coil, and arbuscule. The structure of AMF in plant roots proved that AMF is symbiotic with adaptive plants in gold tailings. This research also proved that AMF can accelerate vegetation succession on degraded land including gold tailings land. This group of fungi is an important component of restoration on degraded land. Rillig et al. (2002, 2005), reported that AMF can improve soil structure at macro aggregate and micro aggregate levels. AMF can also increase the composition and productivity of plant communities (van der Heijden et al. 1998).

\section{AMF spores}

Based on the results of the identification of AMF spore morphology, seven types of AMF were found symbiotic with adaptive plants located on the gold post-mining site in Bombana, Southeast Sulawesi. The seven types of AMF were:

\section{Glomus aggregatum N.C. Schenck \& G.S. Sm}

The spores were globose, aggregate, pale yellow in color and measured 36-72 $\times 36-66 \mu \mathrm{m}$. Spore surface was found slippery. Sticky hyphae were light yellow in color. This species is associated with plants including Calopogonium mucunoides, Hyptis capitata, Imperata cylindrica, Paspalum conjugatum, Saccharum spontaneum, and Setaria parviflora.

Glomus aggregatum found in this study has similar characteristics with Glomus aggregatum mentioned in several previous publications. However, the spore size was greater compared that reported by Haerida and Kramadibrata (2002) from corn rhizosphere (14.4-57.6 $\times$ 14.4-39.7 $\mu \mathrm{m})$, and smaller compared with that of reported by Koske (1985) from the rhizosphere of Ammophila breviligulata and Equisetum arvense. The spore size of $G$. aggregatum had relatively similar size to that reported by
Widiastuti and Kramadibrata (1992) from the rhizosphere of corn $(40-50 \times 40-50 \mu \mathrm{m})$.

This type of fungi has been reported from Java, namely from the oil palm rhizosphere (Widiastuti and Kramadibrata 1992), soybeans (Kramadibrata et al. 1995), maize (Haerida and Kramadibrata (2002), natural forests of Gunung Halimun National Park, (Suciatmih and Kramadibrata 2002), Durio zibethinus (Chairani et al. 2002), Orania sylvicola (Aradea 2004), Chrysophyllum cainito (Destifani 2013), and Sandoricum koetjape (Ginting 2013). Notes from Southeast Sulawesi and Bali, each type of fungi reported -one in the rhizosphere of wood nails (Husna et al. 2014; 2015) and Anacardium occidentale L. (Proborini et al. 2013).

\section{Sclerocystis sinuosa Gerd. \& B.K. Bakshi}

Grouped spores form a sporocarp that is compact, pungent and brown. No data of size was measured because of the damaged spores. The surface of the spore was slippery and shaped like a mace. Short hyphae were light yellow to dark yellow. This AMF species were found associated with plants Aeschynomene indica, Chromolaena odorata, Eupatorium sp., Mikania cordata, Paspalum conjugatum, Saccharum spontaneum, Setaria parviflora, and Trema orientalis.

Sclerocystis sinuosa has been reported in Java in the Theobroma cacao rhizosphere (Kramadibrata 2009), natural forest plants in Ujung Kulon National Park's (Kramadibrata 2012), Pandanus tectorius in Java and Madura (Kramadibrata 2013). In Sumatra, it has been reported from the rhizosphere of Mangifera indica L. in a community garden on the island of Enggano (Kramadibrata 2016).

\section{Acaulospora scrobiculata Trappe}

The spore of this AMF type is single, globose, pale yellow to yellow in color and has a measurement of 75 (96) $-96(120) \times 75(-96)-96(-120) \mu \mathrm{m}$. Spore surface has ornamentation of evenly spaced, linear elliptical crescentlike form. This species is found in the rhizosphere of plants Acacia mangium, Bothriochloa bladhii, Calopogonium mucunoides, Cyperus sp, Chromolaena odorata, Digitaria longiflora, Desmodium gangeticum, Eupatorium sp., Hyptis capitata, Imperata cylindrica, Leptocloa. chinensis, Muntingia callabura, Paspalum conjugatum, Porophyllum ruderale, Uraria lagopodoides, and Setaria parviflora.

Acaulospora scrobiculata obtained has similar characteristics with several A. scrobiculata mentioned in previous publications, but the size of the spore is smaller compared to that reported in Java from Widiastuti and Kramadibrata (1993) from the oil palm rhizosphere at Kertajaya $(80-110 \times 80-120 \mu \mathrm{m})$; Kramadibrata et al. (1995) from the rhizosphere of soybean $(96-125 \times 96-135 \mu \mathrm{m})$; Haerida and Kramadibrata (2002) from the rhizosphere of corn $(80-110 \times 80-120 \mu \mathrm{m})$; Kramadibrata (2012) in the rhizosphere of forest plants in Ujung Kulon National Park (135-180x150-180 $\mu \mathrm{m})$ Kramadibrata (2013) from the rhizosphere of Pandanus tectorius $(90-130 \times 90-210 \mu \mathrm{m})$ and on Sumatra Island, from agricultural land and natural forest on Enggano Island (130-250 $\mu \mathrm{m}$ ) (Kramadibrata 2016). 
Table 2. AMF colonization in adaptive plant roots in gold tailings at PT. Panca Logam Makmur, Bombana, Indonesia

\begin{tabular}{|c|c|}
\hline Plant species* & $\begin{array}{c}\text { Coloni- } \\
\text { zation }(\%)\end{array}$ \\
\hline Paspalum commersonii Lam. & 97 \\
\hline Galianthe peruviana (Pers.) E.L.Cabral & 93 \\
\hline Melochia corchorifolia $\mathrm{L}$. & 93 \\
\hline Ageratum conizoides (L.) L. & 90 \\
\hline Anaphalis sp. & 90 \\
\hline Eupatorium sp. & 90 \\
\hline Passiflora foetida $\mathrm{L}$. & 90 \\
\hline Uraria lagopodoides L. (DC) & 90 \\
\hline Calopogonium mucunoides Desv. & 87 \\
\hline Melastoma malabatricum (L.) Smith & 87 \\
\hline Capillipedium panviflorum (R.Br) Stapf & 83 \\
\hline Cyanthillium cinerum L.H.Rob & 83 \\
\hline Blumea sp. & 80 \\
\hline Hyptis capitata Jacq & 80 \\
\hline Lygodium flexuosum (L.) Sw. & 80 \\
\hline Acacia mangium Willd. & 77 \\
\hline Desmodium gangeticum DC & 77 \\
\hline Mikania cordata (Burm.f) B.L. Rob. & 77 \\
\hline Oxalis corniculata $\mathrm{L}$. & 77 \\
\hline Setaria parviflora (Poir.) M. Kerguelen & 77 \\
\hline Trema orientalis (L.) Blume & 77 \\
\hline Aeschynomene indica $\mathrm{L}$. & 73 \\
\hline Alstonia scholaris (L.) Br.R & 73 \\
\hline Chyperus sp. & 73 \\
\hline Crotaralia micans Link. & 73 \\
\hline Digitaria longiflora (Rezt) Pers. & 73 \\
\hline Eclipta prosstrata $\mathrm{L}$. & 73 \\
\hline Mimosa pudica $\mathrm{L}$. & 73 \\
\hline Neolamarckia macrophylla (Roxb.) Bosser & 73 \\
\hline Neolamarckia cadamba (Roxb.) Miq. & 73 \\
\hline Paspalum conjugatum P.J. Bergius & 73 \\
\hline Phyllanthus niruri L. & 73 \\
\hline Porophyllum ruderale (Jacq) Cass & 73 \\
\hline Solanum torvum $\mathrm{Sw}$. & 73 \\
\hline Chormolaena odorata (L.) R.M. King \& H. Rob. & 70 \\
\hline Festuca mairei St.-Yves & 70 \\
\hline Oldenlandia herbaceae (L.) Roxb. & 70 \\
\hline Phyllodium pulehellum (L.) Desv. & 70 \\
\hline Imperata cylindrica $\mathrm{L}$ & 67 \\
\hline Leucaena leucocephala (Lam.) de Wit & 67 \\
\hline Macaranga tentaculata Airy Shaw & 67 \\
\hline Polygala chinensis $\mathrm{L}$. & 67 \\
\hline Saccharum spontaneum $\mathrm{L}$. & 67 \\
\hline Smilax sp. & 67 \\
\hline Cyperus ratundus $\mathrm{L}$ & 63 \\
\hline Oldenlandia diffusa (Willd.) Roxb. & 63 \\
\hline Hyptis brevipes Poit. & 60 \\
\hline Muntingia callabura $\mathrm{L}$. & 60 \\
\hline Bothriochloa bladhii (Rezt.) Blake & 57 \\
\hline Leptocloa chinensis (L.) Nees & 57 \\
\hline Osbeckia chinensis $\mathrm{L}$. & 57 \\
\hline Cheysopogon aciculatus (Retz.) Trin. & 50 \\
\hline Fimbiristylis sp. & 43 \\
\hline Averages & 73.9 \\
\hline
\end{tabular}

In addition to the plants mentioned above, in Java: $A$. scrobiculata is also found in the rhizosphere of various types of bamboo (Setya et al. 1995; Kramadibrata et al. 2007), Garcinia mangostana (Silviana et al. 1999),
Colocasia esculenta L. (Wulandari 2001), Theobroma cacao (Kramadibrata 2009), Nephelium lappaceum (Muliawan et al. 2002), Durio zibethinus (Chairani et al. 2002). In natural vegetation, this AMF type has been reported in various types of rhizosphere of Iwul forest plants (Orania sylvicola), in Dungus Iwul Nature Reserve (Aradea 2004), coastal forest at Ujung Genteng, Sukabumi Selatan (Puspitasari 2005). This AMF type has also been reported from various rhizosphere of forest plants in Ujung Kulon National Park, (Kramadibrata 2012), on Pandanus tectorius in Tasikmalaya, Kebumen and Bangkalan, Madura (Kramadibrata 2013), Artocarpus elasticus (Kramadibrata 2013), various types of Areca in Bogor Botanical Gardens (Fahriny 2013), Chrysophyllum cainito in Bogor (Destifani 2013). In Bali: Anacardium occidentale L. (Proborini et al. 2013). Sulawesi: in Saccharum officinarum plants (Kumalawati et al. 2014), and Pericopsis mooniana in Kolaka, Southeast Sulawesi (Husna et al. 2014). Sumba: various types of bamboo (Kramadibrata 2011).

Acaulospora tuberculata Trappe

The spores were globose, yellowish in color, single, and measured $153-186 \times 156-180 \mu \mathrm{m}$ in size. Spore surface has ornamentation of smooth heads, dense and uniform. This type was found spread in the rhizosphere of Digitaria longiflora, Galianthe peruviana, Hyptis capitata, Imperata cylindrica, Muntingia callabura, Saccharum spontaneum, and Setaria parviflora.

Acaulospora tuberculata Trappe obtained in this research has similar characteristics with Acaulospora tuberculata mentioned in several previous publications. However, the spore size is larger $(153-186 \times 153-180 \mu \mathrm{m})$ than the spores reported by Kramadibrata (2012) in the rhizosphere of forest plants in TN Ujung Kulon $(60(100 \times$ $45-65 \mu \mathrm{m})$ and from Enggano Island (150-180 $\mu \mathrm{m})$ (Kramadibrata 2016). The spore size is relatively the same as that reported by Kramadibrata (2013), but the spore size is smaller compared to the one reported by Ningsih et al. (2013) and Kramadibrata (2013).

Acaulospora tuberculata has been reported in the island of Java in the Elaeis guineensis rhizosphere (Widiastuti and Kramadibrata 1993), Garcinia mangostana (Silviana et al. 1999), Colocasia esculenta (Wulandari 2001), Durio zibethinus (Chairani et al. 2002), Orania sylvicola (Aradea 2004), coastal forest vegetation of Sukabumi (Puspitasari 2005), Bamboo (Kramadibrata et al. 2007; Kramadibrata 2011), Theobroma cacao (Kramadibrata 2009), Diospyros blancoi (Ningsih et al. 2013), Sandoricum koetjape (Ginting 2013), Areca (Fahriny 2013), forest vegetation in Ujung Kulon National Park (Kramadibrata 2012) and Baturaden Botanical Gardens and Mount Slamet, Central Java (Kramadibrata 2013), Pandanus tectorius in Tasikmalaya, Kebumen and Bangkalan (Kramadibrata 2013). This type of Sumatra is symbiotic with Glycine max (Kramadibrata et al. 1995) and banana, bamboo, cocoa and secondary forest vegetation on Enggano Island (Kramadibrata 2016). This type was also reported in Sulawesi in the rhizosphere of Saccharum officinarum (Kumalawati et al. 2014) and Bali from the rhizosphere of Anacardium occidentale L. (Proborini et al. 2013). 


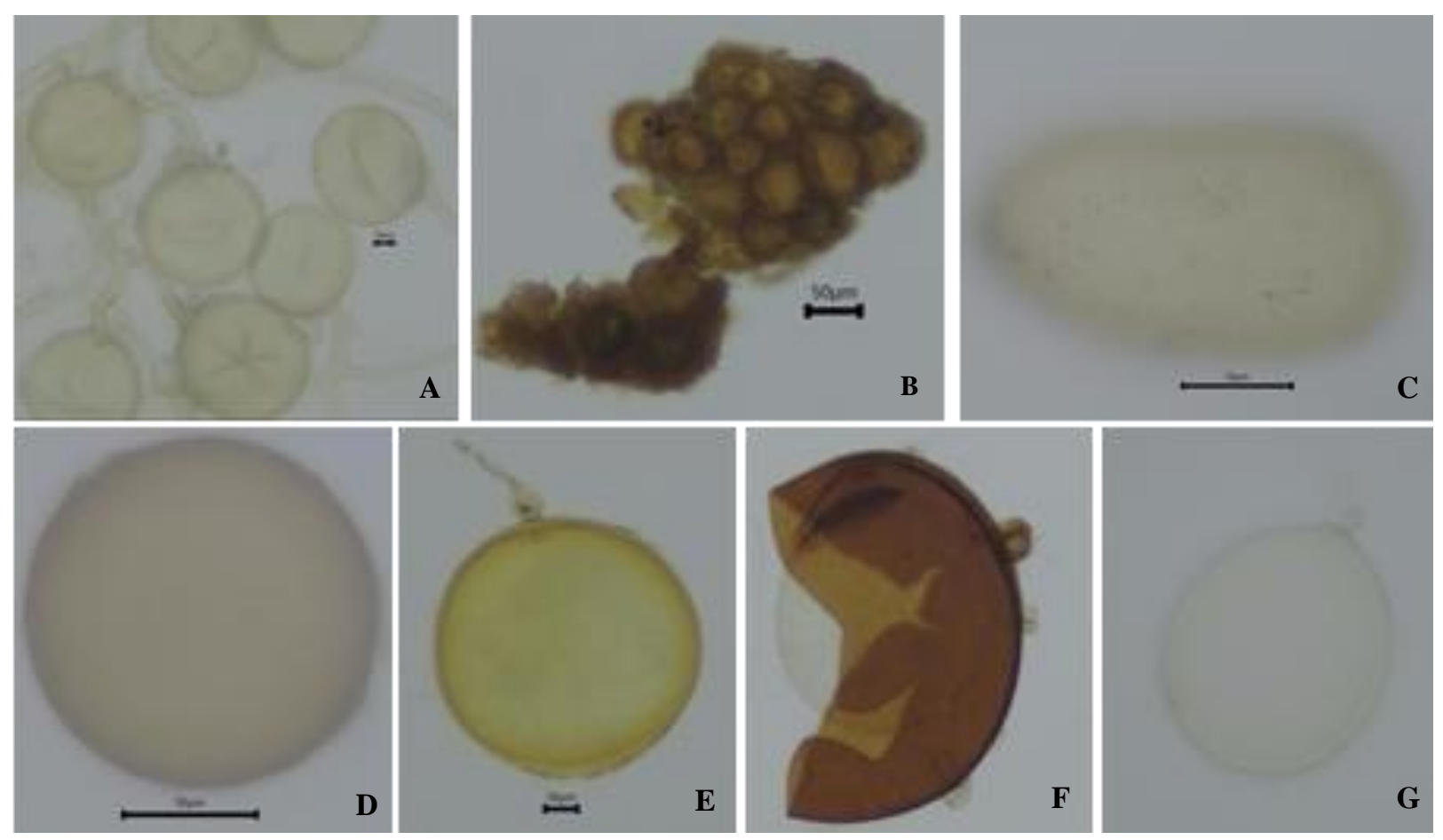

Figure 2. The types of AMF found in the rhizosphere of pioneer plants that grow naturally in gold tailings land at PT. Panca Logam Makmur, Bombana, Southeast Sulawesi, Indonesia. A. Glomus aggregatum. B. Sclerocystis sinuosa. C. Acaulospora scrobiculata, D. A. tuberculata, E. Scutellospora pellucida, F. Scutellospora sp.1, G. Glomus sp.1 (Photographs by Idang Sumanta)

Scutellospora pellucida (Nicol. \& N.C. Schenk) C. Walker \& F.E Sanders

The spores were globose, single, hyaline to yellow in color, measured $105(-200)-186-386) \times 86(-286)-200$ (386) $\mu \mathrm{m}$ in size. Spore surface was slippery. S. pellucida had never been reported in Indonesia. S. pellucida was first discovered in the northern and central parts of Florida, United States of America by Nicolson and Schenk (1979) and in 1986 it was reported to be found in sand dunes by Koske and Walker (1986). This species is spread in the rhizosphere of plant Acacia mangium, Ageratum conizoydes, Alstonia scholaris, Anaphalis sp., Blumea sp., Bothriochloa bladhii, Calopogonium mucunoides, Capillipedium panviflorum, Cheysopogon aciculatus, Crotaralia micans, Chromolaena odorata, Cyanthillium cinerum, Cyperus ratundus, Cyperus sp, Desmodium gangeticum, Digitaria longiflora, Eclipta prosstrata, Galianthe peruviana, Gulina fimbiristylis, Hyptis capitata, Imperata cylindrica, Leptocloa chinensis, Leucaena leucocephala, Lygodium flexuosum, Macaranga tentaculata, Melochia corchorifolia, Melastoma malabatricum, Mikania cordata, Muntingia callabura, Neolamrkia macrophylla, Neolarmakia cadamba, Oldenlandia diffusa, Osbeckia chinensis, Oxalis corniculata, Paspalum commersonik, Paspalum conjugatum, Porophyllum ruderale Polygala chinensis, Saccharum spontaneum, Setaria parviflora, Trema orientalis, and Uraria lagopodoides.

\section{Scutellospora $s p .1$}

The spore was globose, single, reddish brown in color, and measured $87(-186)-120(-229) \times 87(-143)-120(-$
257) $\mu \mathrm{m}$ in size. Spore surface was smooth. This AMF species was found associated with plants Bothriochloa bladhii, Calopogonium mucunoides, Imperata cylindrica, Neolamarkia cadamba, Leptocloa chinensis, and Saccharum spontaneum.

\section{Glomus sp.}

The spores was single, oval-shaped, pale yellow in color, with $36(-195)-75(150) \times 48(-129)-84(-174) \mu \mathrm{m}$ size. Spore surface was slippery. The AM fungal species was found associated with plants of Acacia mangium, Alstonia scholaris, Calopogonium mucunoides, Cyperus sp., Chromolaena odorata, Digitaria longiflora, Desmodium gangeticum, Hyptis capitata, Imperata cylindrica, Leucaena leucocephala, Muntingia callabura, Mikania cordata, Neolamrkia cadamba, Paspalum conjugatum, Porophyllum ruderale, Saccharum spontaneum, Setaria parviflora, and Trema orientalis.

In conclusion, adaptive plants of three years in age grown in gold tailings land are symbiotic with seven types of Arbuscular mycorrhizal fungi. The seven types of AMF were Glomus aggregatum, Sclerocystis sinuosa, Acaulospora scrobiculata, A. tuberculata, Scutellospora pellucida, Glomus sp., and Scutellospora sp.1. Three AM fungi namely, Sclerocystis pellucida, S. sinuosa, and A. scrobiculata are new records for the distribution of AMF in Indonesia, Sulawesi and Southeast Sulawesi. 


\section{ACKNOWLEDGEMENTS}

This research was funded through Fundamental Research National No. 513g/UN29.20/PPM/2019 from the Ministry of Research, Technology, Indonesia. The authors also thank the Chairman of PT. Panca Logam Makmur for providing research site.

\section{REFERENCES}

Achard F, Eva HD, Stibig HJ, Mayaux P, Gallego J, Richards T, et al 2002. Determination of deforestation rates of the world's humid tropical forests. Science 297: 999-1002.

Aradea NN. 2004. Arbuscular mycorrhizal fungi (AMF) on Iwul (Orania sylvicola). Floribunda 2 (6): 164-170.

Brundrett M, Bougher N, Dell B, Grove T, Majalaczuk. 1996. Working with Mycorrhizas in Forestry and Agriculture. Australian Centre for International Agriculture Research, Canberra.

Chairani, Gunawan AW, Kramadibrata K. 2002. Mikoriza durian di Bogor dan sekitarnya. J Mikrobiol Indones 7: 44-46. [Indonesian]

Delvian, Elfiati D, Hartini KS, Sipayung J, Sihombing S. 2016 Inventarisasi tumbuhan pionir dan fungi mikoriza potensial pada lahan bekas tambang untuk kegiatan reklamasi. Materi presentasi Seminar Nasional BKS-PTN Bidang Ilmu Pertanian. Medan. Agustus 2016. [Indonesian]

Destifani YF. 2013. Arbuscular Mycorrhizal Fungi on Star Apple (Chrysophyllum cainito) at IPB Darmaga Campus. [Thesis]. Institu Pertanian Bogor, Bogor. [Indonesian]

Fahriny RA. 2013. Arbuscular mycorrhizal diversity of Areca in Bogor Botanical Garden. [Thesis]. Institut Pertanian Bogor, Bogor. [Indonesian]

Ginting F. 2013. Arbuscular mycorrhizal fungi on Kechapi (Sandoricum koetjape) at LIPI Cibinong. [Thesis]. Institut Pertanian Bogor, Bogor. [Indonesian]

Gerdemann JW, Nicolson TH. 1963. Spores of mycorrhizal endogone species extracted from soil by wet sieving and decanting. Trans $\mathrm{Br}$ Mycol Soc 46: 235-244.

Haerida I, Kramadibrata K. 2002. Identification of arbuscular mycorrhizal fungi on corn rhizosphere in Java. Floribunda 2 (2): 33-37.

Husna, Budi SWR, Mansur I, Kramadibrata K. 2014. Fungi mikoriza arbuskula pada rizosfer Pericopsis mooniana (Thw.) Thw. di Sulawesi Tenggara. Berita Biol 13 (3): 263-273. [Indonesian]

Husna, Budi SWR, Mansur I, Kusmana C. 2015. Diversity of arbuscular mycorrhizal fungi in the growth habitat of kayu kuku (Pericopsis mooniana Thw.) in Southeast Sulawesi. Pak J Bio Sci 18 (1): 1-10.

Husna, Tuheteru FD, A Arif. 2018. Arbuscular mycorrhizal fung symbiosis and conservation of endangered tropical legume trees. In: Giri B et al. (eds) Root Biology, Soil Biology 52. Springer, Germany.

Jean-Philippe SR, Franklin JA, Buckley DS, Hughes K. 2011. The effect of mercury on trees and their mycorrhizal fungi. Environ Pollut 159: 2733-2739.

Jeffries P, Gianinazzi S, Perotto S, Turnau K, Barea JM. 2003. The contribution of arbuscular mycorrhizal fungi in sustainable maintenance of plant health and soil fertility. Biol Fertil Soils 37: $1-16$.

Koske RE. 1985. Glomus aggregatum emended: a distinct taxon in the Glomus fasciculatum complex. Mycologia 77: 619-630.

Koske RE, Walker C. 1986. Species of Scutellospora (Endogonaceae) with smooth-walled spores from maritime sand dunes: two new species and a redescription of the spores of Scutellospora pellucida and Scutellospora calospora. Mycotaxon 27: 219-235.

Kramadibrata K, EI Riyanti, Simanungkalit RDM. 1995. Arbuscular mycorrhizal fungi from the rhizospheres of soybean crops in Lampung and West Java. BIOTROPIA 8: 30-38. [Indonesian]

Kramadibrata K. 2011. Arbuscular fungi of bamboo in Sumba Island. Berita Biol10 (5): 635-639. [Indonesian]

Kramadibrata K. 2012. Arbuscular fungi in Ujung Kulon National Park. Berita Biol 11 (2): 205-209.

Kramadibrata K. 2013. Diversity of glomeromycota in Baturaden Botanic Garden and its surrounding area in Slamet Mountain. Berita Biol 12 (2): 217-227. [Indonesian]
Kramadibrata K. 2016. Diversity of arbuscular fungi in Enggano Island. Berita Biol 15 (3): 257-265. [Indonesian]

Kramadibrata K. 2009. The distribution of Glomeromycota in cacao rhizosphere in Indonesia. J Taxon Bot Plant Soc Ecol 12 (5): 347-356.

Kramadibrata K, Prastyo H, Gunawan AW. 2007. Arbuscular fungi of bamboo in Java. Berita Biol 8 (6): 531-536. [Indonesian]

Kumalawati Z, Musa Y, Amin N, Asrul Laode, Ridwan I. 2014. Exploration of arbuscular mycorrhizal fungi from sugarcane rhizosphere in South Sulawesi. Int J Sci Technol Res 3 (1): 201-203.

Muliawan J, Gunawan AW, Kramadibrata K. 2002. Mycorrhiza of rambutan in Bogor area and its surroundings [Komunikasi pribadi]. J Mikrobiol Indones 7 (1): 24-25. [Indonesian]

Ningsih DR, Kramadibrata K, Gunawan AW. 2013. Arbuscular mycorrhizal fungi associated with Bisbul (Diospyros blancoi). Biotropia 20 (2): 112-121. [Indonesian]

Phillips JM, Hayman DS. 1970. Improved procedures for clearing and staining parasitic and vesicular-arbuscular mycorrhizae fungi for rapid assessment of infection. Trans Br Mycol Soc 55: 158-161.

Proborini MW, Sudana M, Suarna W, Ristiati NP. 2013. Indigenous vesicular arbuscular mycorrhizal (VAM) Fungi in cashew nut (Anacardium occidentale L.) plantation at North East-Bali IslandIndonesia. J Biol Agric Healthcare 3 (3): 114-121.

Puspitasari RT. 2005. Keanekaragaman Cendawan Mikoriza Arbuskula (CMA) di Hutan Pantai Ujung Genteng, Sukabumi-Jawa Barat. [Thesis]. Institut Pertanian Bogor, Bogor. [Indonesian]

Redecker D, Schüßler A, Stockinger H, Stürmer SL, Morton JB, Walker C. 2013. An evidence-based consensus for the classification of arbuscular mycorrhizal fungi (Glomeromycota). Mycorrhiza 23: 515531.

Rillig MC, Lutgen ER, Ramsey PW, Klironomos J.N., Gannon, J.E. 2005. Microbiota accompanying different arbuscular mycorrhizal fungal isolates influence soil aggregation. Pedobiologia 49: 251-259.

Rillig MC, Wright SF, Eviner V. 2002. The role of arbuscular mycorrhizal fungi and glomalin in soil aggregation: comparing effects of five plant species. Plant Soil 238: 325-333.

Schenck NC, Perez Y. 1990. Manual for The Identification of VA mycorrhizal fungi. University of Florida. Gainesville, FL.

Schüßler A, Walker C. 2010. The Glomeromycota. A species list with new families and new genera. The Royal Botanic Garden Kew, Kew (GB).

Setya AP, Gunawan AW, Kramadibrata K. 1995. Arbuscular mycorrhizal fungi isolated from bamboo in Bogor Botanic Gardens. Hayati 2 (2): 85-86. [Indonesian]

Sheoran V, Sheoran AS, Poonia P. 2010. Soil reclamation of abandoned mine land by revegetation: a review. Int J Soil Sediment $\begin{array}{llll}\text { Water } & 3 & (2): & \text { Article }\end{array}$ https://scholarworks.umass.edu/intljssw/vol3/iss2/13

Silviana, AW Gunawan, K Kramadibrata. 1999. Biodiversity of Arbuscular mycorrhizal fungi in the rhizospheres of mangosteen. In: Smith FA, Kramadibrata K, Simanungkalit RDM, Sukarno N, Nuhamara ST (eds) Proceedings of International Conference on Mycorrhizas in Sustainable Tropical Agriculture and Forest Ecosystems. The Indonesian Institute University (LIPI), Bogor Agricultural University, and The University of Adelaide, Australia. Bogor-Indonesia. October 27-30, 1997. [Indonesian]

Smith SE, Read DJ. 2008. Mycorrhizal Symbiosis. Academic Press, New York.

Straker CJ, Weiersbye IM, Witkowski ETF. 2007. Arbuscular mycorrhiza status of gold and uranium tailings and surrounding soils of South Africa's deep level gold mines: I. Root colonization and spore levels. South Afr J Bot 73: 218-225.

Suciatmih, Kramadibrata K. 2002. Arbuscular mycorrhizal fungi at different ecosystems of Gunung Halimun National Park. Berita Biol 6 (1): 145-149. [Indonesian]

Suharno, RP Sancayaningsih, ES Soetarto, RS Kasiamdari. 2014. Keberadaan fungi mikoriza arbuskula di kawasan tailing tambang emas Timika sebagai upaya rehabilitasi lahan ramah lingkungan. J Manusia Lingkungan 21 (3): 295-303. [Indonesian]

Suharno, RS Kasiamdari, ES Soetarto, RP Sancayaningsih. 2016. Presence of arbuscular mycorrhizal fungi on fern from tailing deposition area of gold mine in Timika, Indonesia. Intl $\mathbf{J}$ Environ Bioremed Biodegrad 4 (1): 1-7.

Suharno, Soetarto ES, Sancayaningsih RP, Kasiamdari RS. 2017. Association of arbuscular mycorrhizal fungi (AMF) with Brachiaria precumbens (Poaceae) in tailing and its potential to increase the growth of maize (Zea mays). Biodiversitas 18: 433-441. 
Tuheteru FD, Wu QS. 2017. Arbuscular mycorrhizal fungi and tolerance of waterlogging stress in plants. In: Wu QS (eds) Arbuscular Mycorrhizas and Stress Tolerance of Plants. Springer, Singapore.

Utomo WH, Suntari R, Arfarita N, Suhartini Handayanto E. 2014. Rehabilitation of artisanal small gold mining land in West Lombok, Indonesia: 3. Exploration of indigenous plant species and the associated mycorrhiza for phytomycoremediation of mercurycontaminated soils. Am-Eur J Sustain Agric 8 (1): 34-41.

van der Heijden MGA, Klironomos JN, Ursic M et al. 1998. Mycorrhizal fungal diversity determines plant biodiversity, ecosystem variability and productivity. Nature 396: 69-72.
Wang F. 2017. Occurrence of arbuscular mycorrhizal fungi in miningimpacted sites and their contribution to ecological restoration: mechanisms and applications. Crit Rev Environ Sci Technol 47: 1901-1957.

Widiastuti H, Kramadibrata K. 1992. Vesicular-arbuscular mycorrhizal fungi on selected acid soil of West Java. Menara Perkebunan 60 (1): 9-19. [Indonesian]

Widiastuti H, Kramadibrata K. 1993. Identification of vesicular-arbuscular mycorrhizal fungi at selected oil palm estates of West Java. Menara Perkebunan 61 (1): 13-19. [Indonesian]

Wulandari DR. 2001. Mikoriza Vesikula Arbuskula pada Talas. [Thesis]. Institut Pertanian Bogor, Bogor. [Indonesian] 